\title{
Financial Performance of Entry Mode Decisions: Effects of Control in an Internationalization Context
}

\author{
Anna Marie Dyhr Ulrich ${ }^{1}$, Britta Boyd $^{1} \&$ Svend Hollensen $^{1}$ \\ ${ }^{1}$ Department of Border Region Studies, University of Southern Denmark, Sønderborg, Denmark \\ Correspondence: Anna Marie Dyhr Ulrich, Department of Border Region Studies, University of Southern \\ Denmark, Alsion 2, DK-6400 Sønderborg, Denmark. Tel: 45-6550-1775. E-mail: amdu@sam.sdu.dk
}

Received: August 24, 2012 Accepted: September 14, 2012 Online Published: November 9, 2012

doi:10.5539/ijbm.v7n24p12 URL: http://dx.doi.org/10.5539/ijbm.v7n24p12

\begin{abstract}
Based on a survey of 170 Danish SMEs the paper examines influences on entry mode choices and the financial outcome of these decisions. The main research objectives are divided into two steps: Step 1: To determine the factors influencing the choice of foreign entry modes by Danish companies. Step 2: To determine the relationship between the choice of entry mode and export performance, measured in terms of financial outcome. Drawing from transaction cost theory the authors develop and test a model where different factors affect the level of control chosen by the parent company. This study contributes to the existing entry mode theory by integrating both steps into a theoretical framework that offers substantive explanation of the connection between independent entry mode variables, the choice of entry mode and the resulting export performance. Personal networks and interruption of international activities were the most significant factors for the choice of intermediate modes. The results also show that high control modes can positively affect the bottom line profit through higher market investments and better implementation of cross border strategies. Finally, further research suggestions and implications are provided for companies willing to invest more into foreign markets in order to achieve a higher degree of control and better financial results.
\end{abstract}

Keywords: entry mode decisions, bottom line profit, control of parent company, financial performance, internationalization of Danish SMEs

\section{Introduction}

Today companies are characterized by a high degree of globalization and internationalization independently of their size. Internationalization decisions of SMEs include the determination of foreign markets in which they wish to operate and the structural nature of their activities in those markets (Carazo \& Lumiste, 2010). A careful market selection involves analysing strategic needs and orientation of the firm beforehand. Detailed operations in foreign markets have to be determined after the company has chosen which foreign market to enter (Kumar, Stam \& Joachimsthaler, 1994; Papadopoulos, 1988). The operations in the market depend on the firm's choice of foreign entry mode.

International research shows that the chosen entry mode has significant implications on performance and it determines whether a company has full control over the foreign unit or has to share control with a partner (Canabal \& White, 2008; Arregle, Hébert \& Beamish, 2006). Moreover the entry mode decision has long-term consequences for the company because once established it is difficult to change (Brouthers \& Hennart, 2007). The choice of foreign entry modes in a control perspective has been investigated in a previous study based on a survey from the Confederation of Danish Industry with a final sample size of 170 Danish SMEs (Hollensen, Boyd \& Dyhr Ulrich, 2011). Results of this investigation confirm that the most deciding factor for the choice of high control entry mode (subsidiary) was the factor turnover. The factors personal networks and the interruption of the international activities were the most significant factors for the choice of intermediate modes with a medium level of control.

These arguments motivate this study, of which the two main research objectives are:

1) To determine the factors influencing the choice of foreign entry modes by Danish companies

2) To determine the relationship between the choice of entry mode and export performance, measured in terms of financial outcome. 
The preliminary research model can be illustrated in the following way (Figure 1):

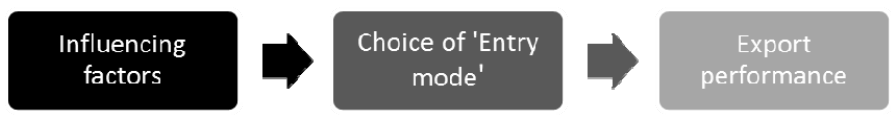

Figure 1. The preliminary research model

Traditionally, entry mode studies have concentrated either on step 1 (e.g. Rasheed, 2005; Carazo \& Lumiste, 2010) or step 2 (Oliveira, Cadogan \& Souchon, 2012; Sousa, Martinez-Lopez \& Coelho, 2008). This study contributes to the existing entry mode theory by integrating both steps into a theoretical framework that offers substantive explanation of the connection between independent entry mode variables, the choice of entry mode and the resulting export performance.

Consequently, this survey is novel in arguing that high control modes result in a higher bottom line profit through higher investments in the market and better implementation of cross border strategies. We extend previous research where higher financial bottom line results were expected by exploiting ownership advantages through high control entry modes (Berbel-Pineda \& Ramirez-Hurtado, 2011; Qian, 1998; Brouthers, Brouthers \& Werner, 2003). The study enhances the understanding of links between different entry modes and export performance. Such knowledge connection provides managers with guidelines for choosing the most profitable entry mode.

The paper is formatted into several sections. First, the relevant literature focussing on entry mode and export performance is reviewed. Second, the research model is presented based on different internal factors influencing the entry mode decision. Major attention is here paid to financial export performance as a result of the entry mode decision. Third, the methodology and data analysis are described through examining several hypotheses. Fourth, the survey results are presented and discussed. Finally, managerial implications are highlighted, and directions for future research are identified.

\section{Theory}

An entry mode can be defined as an institutional arrangement for organizing and conducting international business transactions by which all future decisions are influenced (Andersen, 1997; Kumar \& Subramaniam, 1997). In the entry mode literature 'control' is an important construct because it is an indicator for determining potential risks and returns on assets for firms entering foreign markets (Anderson \& Gatignon, 1986).

In principal, a company can enter a foreign market through the following three categories of entry modes (Hollensen et al., 2011; Hollensen, 2010):

1) High control entry modes involve foreign direct investment (FDI) in form of wholly owned subsidiaries (WOS), or direct selling to original equipment manufacturers (OEM) as big customers. Both entry modes are equal to full control with activities in foreign markets.

2) Intermediate entry modes include strategic alliances (SA) and joint ventures (JV) which are positioned in-between high and low control modes. Within this category of entry modes partners agree to share resources, technology, profits, and jobs, and supplement each other's needs for a long period of time. Unlike a joint venture company, a strategic alliance does not involve the formation of a new company. In such a cooperation the local partner typically provides market-specific knowledge, such as marketing and relationship skills that are important to the parent companies' activities in new foreign markets.

3) Low control modes consist of indirect and direct export. Indirect export represents the lowest degree of control of the activities in the foreign market. It occurs when the parent company uses independent companies located in the parent company's own country or third country (Peng \& York, 2001). Direct export occurs when the parent company sells directly through an agent, distributor or importer located in the foreign market area.

The choice of an appropriate foreign entry mode is a difficult and complex task for the firm management (Hill Hwang \& Kim, 1990). Each foreign market entry mode represents a continuous international expansion involving different levels of control, flexibility and risks.

The choice of entry mode often involves some trade-offs. A high control mode can increase the resource commitment and profitability, but at the expense of risk and flexibility (Sanchez-Peinado, Pla-Barber, \& Hébert, 2007, Musso \& Francioni, 2012). A low control mode diminishes the commitment of resources, and also increases the degree of flexibility; but frequently at the expense of profitability (Ekeledo \& Sivakumar, 2004; Chen \& Messner, 2009). It is, however, important to note that an intermediate entry mode may bring a relatively 
high degree of control (Nguyen, 2009). This could for example be the case in joint ventures or tightly run franchise systems.

The theoretical framework is divided into a two-step research process which is also illustrated in Figure 1. First, we look at the determining factors for the choice of entry modes. Then we analyse the outcome or the export performance (measured by the financial impact) of the entry mode decision.

\subsection{Regarding 1. Step: Choice of Entry Mode}

Agarwal and Ramaswami (1992) indicate that the foreign entry mode choice constitutes a commitment of four factors: resources, control, risk and profits.

The focus of this study will mainly be on the internal control aspect in relation to external foreign markets. The reason for this is that the management needs to consider the degree of control that is required over operations in international markets in order to achieve positive bottom line profit results.

Institutional and transaction cost theory are among the most commonly used theories in international entry mode research (Brouthers \& Hennart, 2007). Most of this literature is based on economic theory emphasizing the rational choice in relation to cost-minimization and risk-adjusted return on investment (Nielsen \& Nielsen, 2011; Hennart, 1988; Anderson \& Gatignon, 1986; Williamson, 1985).

According to transaction cost theory, companies should choose entry modes that minimize overall transaction costs. Several factors affect transaction costs when parent companies are dealing with export partners (low-control modes), including opportunism, the costs of monitoring and enforcing the contract with the export partner and the existence of transaction-specific assets (Williamson, 1975). If transaction costs associated with finding, negotiating and monitoring potential export partner firms are low, foreign companies should rely on the market arrangement to deliver products and services (i.e. export modes as low control entry modes). With high transaction costs companies should consider switching to a higher control level or hierarchical entry mode (Erramilli \& Rao, 1993; Gatignon \& Anderson, 1988; Makino \& Neupert, 2000).

Asset specificity is the degree to which company assets (e.g. products and services) are specialized to support trade for only a few parties (Williamson, 1975). A high degree of asset specificity encourages hierarchical or high control modes (Chen, Yang, Hsu \& Wang, 2009), because it increases the costs of switching from one transaction partner to another. This then leads to potential opportunistic behaviour from the export partner (Hill, 1990).

Literature suggests that different modes of foreign entry represent different levels of resource commitment risk and control (Anderson \& Gatignon, 1986). The choice between high, intermediate and low control entry modes depends on the costs and benefits of these three options (Hennart, 1988; Williamson, 1985).

A JV is the pooling of assets in a common and separate organization by two or more firms, resulting in lower commitment and shared ownership, risk and control. When market transactions or contracts are subject to high transaction costs in export contracts, sharing equity and resources in form of a JV aligns the incentives of the parties and thus reduces the risk of opportunism. Accordingly, a WOS is chosen when firms seek high control and are willing to make maximum commitment and take on maximum risk (Kogut \& Singh, 1988). While such high control entry mode may result in potentially higher returns, the increased profitability is often accompanied by greater risk (Agarawal \& Ramaswami, 1992).

In this study we have chosen the financial bottom line profit as the consolidating performance construct, according to Figure 1.

\subsection{Regarding 2. Step: Export Performance (Financial Impact)}

Research on export performance has grown considerably during the past decades (e.g., Hultman, Katsikeas \& Robson, 2011; Stoian, Rialp \& Rialp, 2011; Sousa et al., 2008). However, there is yet no full consensus on how to measure export performance (Wheeler, Ibeh \& Dimitratos, 2008). In general, the literature indicates that several factors are influencing export performance related to the choice of entry mode (Sousa et al., 2008; Zou, Taylor \& Osland, 1998). Export performance is thus a complex and multifaceted construct. For example, an increase in market share might express that the company has bought market share by cutting off prices, or investing heavily in promotions. However, the metric itself does not tell whether a company's bottom line profit has actually improved. Furthermore, when a firm is entering a new market, it may accept short-term financial losses as it gains experiential knowledge or develops brand awareness, which may later be important drivers of performance. In addition a study conducted by Hultman, Katsikeas \& Robson (2011) implies that firms have fine-grained experience profiles that can lead to different levels of learning about markets and export 
performance.

Generally, export performance has been measured in at least two different ways (Papadopoulos \& Martín, 2010; Zou et al., 1998). The most common concept focuses on the financial outcome of international marketing activities. Studies adopting this view of export performance have generally measured export performance by indicators such as export sales, export sales growth and export profits (Singh, 2009; Peng \& York, 2001). Another way of conceptualizing export performance is based on capturing the strategic outcome of exporting. This view includes the attainment of strategic goals such as improved competitiveness or increased market share. In this perspective a strengthened strategic position should be considered an integral part of export performance (Papadopoulos \& Martín, 2010). Consequently, there seems to be a broad consensus that export performance can be considered to be multidimensional (Stoian et al., 2011; Lages, Silva, Styles \& Zulema, 2009; Madsen, 1998). In order to capture export performance Brouthers, Nakos, Hadjimarcou \& Brouthers (2009) discuss both subjective and objective measures. Because of the measurement problems connected to objective export performance measures, Brouthers et al. (2009) end up with using subjective financial outcomes, measured in terms of sales and profits.

For this study, since many dimensions and indicators are relevant to measure success or failure, we use an indicator that consolidates several aspects of the construct (Carneiro, da Rocha \& da Silva, 2011; Brouthers et al., 2009). Consequently, we have chosen to use the financial outcome (the 'financial bottom-line result') as the key export performance indicator.

Therefore, in this study export performance has been measured in terms of managerial satisfaction (perception) with financial outcome of the entry mode choice. More precisely respondents were asked to self-evaluate the importance of the entry mode choice for the financial bottom-line result on a five point scale (not important $=1$; very important $=5$ ). Appendix A shows a selection of questions from the original questionnaire with 80 questions illustrating the focus of this study and how the variables were measured.

\section{Development of Research Model}

Firm's specific factors turn out to be essential in entry mode decisions. One of the pioneering approaches that tried to justify FDI advantage theory is explained in Hymer (1976) \& Kindleberger (1969). According to this conceptual framework, based on industrial economies, a foreign-owned firm must have ownership advantages that allow it to compete with local enterprises on equal terms. This argument is equally mentioned in the first of the three pillars on which Dunning's Eclectic Paradigm (1981) is supported. The other two are internalization advantages (which determine whether the firm will organize its activities through the market or internally) and location advantages (which influence the choice of a target country).

The following research model shows the supposed connection between the dependent variable (choice of entry mode) and the independent variables, represented by the hypotheses H1 to H10:

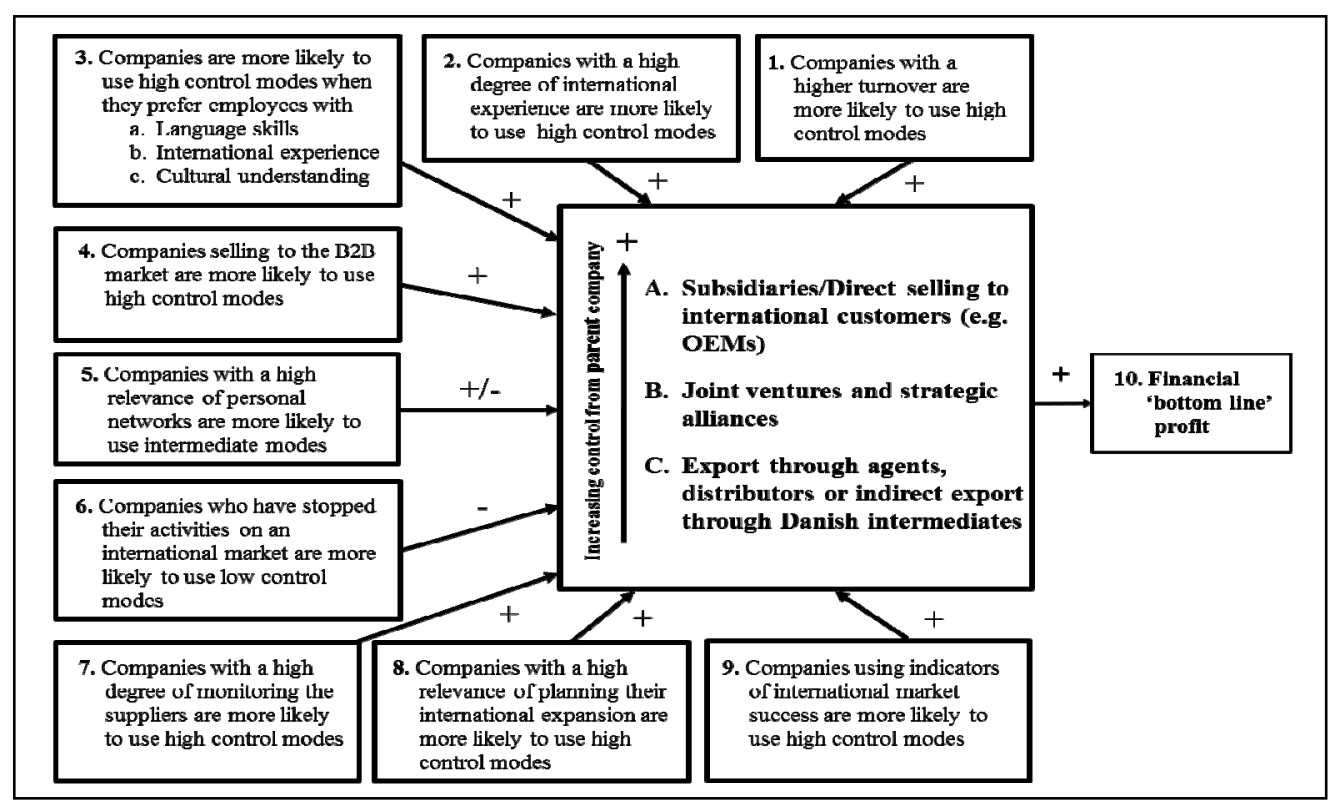

Figure 2. Research model 
Table 1 summarizes the development of hypotheses H1to H9 that focus on the influence that different factors may have on entry mode decisions.

Table 1. Development of hypotheses

\begin{tabular}{lll}
\hline Hypotheses & Theoretical support & References \\
\hline H1: Companies with a & Export entry modes with their lower resource & Carozo \& Lumiste, \\
higher turnover are more & commitment, may be more suitable for SMEs. & 2010; Hollensen, 2010; \\
likely to use high control & & Cumberland, 2006 \\
modes &
\end{tabular}
modes

The inherent risks and fixed costs, the proneness to invest abroad must increase with the size of the firm, measured by number of employees and turnover.

Greater size implies greater availability of financial and managerial resources, which makes it easier to set up full-ownership subsidiaries.

A large part of the empirical research has observed that firm size correlates positively with the degree of commitment, assumed with the entry mode.

Horst, 1972

Tallmand \& FladmodeLindquist, 2002

Ramón, 2002; Trevino \& Grosse, 2002; Quer, Claver \& Rienda, 2007

H2: Companies with a Companies which have accumulated knowledge of high degree of foreign cultures through international assignment international experience experience are better able to cope with uncertainly are more likely to use associated with international operations and thus they high control entry modes

H3: Companies are more likely to use high control entry modes when they prefer employees with Language skills International experience Cultural understanding typically perceive foreign direct investments as less risky than executives without such experience.

International experience skills will reduce the firm's uncertainty about being able to manage a subsidiary in a distant market, making its managers more confident about entering with a high-control entry mode.

Internationally experienced companies are likely to be confident in their ability to accurately estimate risks and returns associated with foreign investments and, as a result, are more aggressive in committing resources and assuming control over foreign operations.

International assignment experience contributes to the development of a "global mindset" that leads to greater confidence in the ability to effectively handle foreign direct investments. This may result in companies with international assignment experience opting for the highest degree of ownership and control in foreign operations.

Companies with international experiences are more likely to prefer full-control entry modes and will favor high control entry modes over low control entry modes. International assignment experience at the employee level helps reduce the uncertainty associated with international expansion.

International experience increase awareness of international opportunities and helps developing employees' superior ability to manage operations in different countries.

Accumulated knowledge about foreign markets is important in overcoming the "psychic distance" of doing business abroad. International experience may serve as a surrogate for implementing an international strategy.
Carpenter et al., 2001

Pehrsson, 2008; Evans, Mavondo \& Bridson 2008

Erramilli, 1991

Tung \& Miller, 1990

Herrmann \& Datta, 2002, 2006

Sambharaya, 1996

Tihanyi, Ellstrand, Daily \& Dalton, 2000

Sambharya, 1996 
H4: Companies selling products to the $\mathrm{B} 2 \mathrm{~B}$ market are more likely to use high control modes

H5: Companies with a high preference for personal networks are more likely to use intermediate modes
H6: Companies who have stopped their activities on an international market are more likely to use export (low control) modes

H7: Companies with a high degree of monitoring suppliers are more likely to use high control modes
International experience helps establish informal networks that support decision-making in international contexts.

From corporate international experience it has been found that extensive experience in general is positively correlated with a choice of high control entry mode.

International experience may be specified with language and cultural experience of different countries or regions.

Companies with internationally experienced employees are more likely to prefer high-control over low control modes when expanding abroad.

The nature of the firm-specific know-how transferred is tacit it is by definition difficult to codify and patent, and can only be acquired by 'learning by doing'.

Tacit know-how makes the drafting of a contract very problematic, because it is a form of knowledge that cannot be verbalized or formalized.

The higher the tacit component of firm-specific knowledge, the more it will favor high control modes.

Network relations result from a firm's efforts to establish long-term relationships with other firms in order to sustain its competitive advantage.

Common backgrounds, such as similar ethnic, geographic, ideological, professional, or historical origins, are the most common grounds for establishing network relations.

Empirical studies have shown that Chinese people were good establishing and operating through personal networks".

The tighter the local distributors' structured network, the more likely it is that the parent company will abandon hierarchical control and opt for a collaborative arrangements in form of intermediate entry modes.

Setting up a wholly owned subsidiary requires the transfer of people and equipment, the purchase, lease or construction of offices and/or manufacturing facilities, and the development of a network of suppliers and customers. There is an opportunity cost of investing resources in one country which may prevent the firm from investing resources in another.

The high risk may eventually result in discontinuation of the company's activities and the loss of company resources in a particular international market.

Companies experience discontinuation of international activities and loss of company resources in one market, are risk-averse at subsequent market entries and prefer low control entry modes.

Planning and control allow firms to safeguard upstream supplies of essential inputs to the production process, co-ordinate activities, ensure the quality of end products, and influence the logistical and marketing activities for the product in the target market .

“... greenfield entry into the UK market will have a relatively positive impact on supplier linkages whereas
Athanassiou \& Nigh, 2002

Ekeledo \& Sivakumar, 2004; Gomes-Casseres, 1989

Chen et al., 2009

Nielsen \& Nielsen, 2011

Hayek, 1945

Polanyi, 1966/1997; Nonaka \& Takeuchi, 1995

Hollensen, 2010

Peng \& Heath, 1996; Thorelli, 1986

Styles \& Ambler, 2003

Peng \& Heath, 1996

Chen et al., 2009; Lin, 2000; Zhang, Zhang \& Liu, 2007

Driscoll \& Paliwoda, 1997

Morschett, SchrammKlein \& Swoboda, 2010

Canabal \& White, 2008; Kouznetsov \& Jones, 2009

Anderson \& Gatignon 1986; Dunning 1981

Williams, 1999 ; Williams, 2005 
merger and acquisition entry will have a relatively negative impact" (Williams, 2005, p.85).

The higher the degree of autonomy given to Zanfei, 2000 subsidiaries by the parent company the greater will be the development of connections with local suppliers.

H8: Companies which When the company chooses an entry mode it is very have planned their often a trade-off between control on the one hand and international expansion are more likely to use high control modes on the other hand the necessary resource commitment. Resource commitment and flexibility are closely linked to each other. High resource commitment reduces the strategic flexibility. When the company selects a high control mode, it then faces a low flexibility and a high resource commitment and the expansion process tends to be more planned.

H9: Companies using When indicators such as market share or profit are used indicators of international for entry mode decisions, the company might prefer a market success are more fully owned marketing subsidiary as entry mode into a likely to use high control certain foreign country. modes

A study of the internationalization of Spanish hotels by the use of high control modes, found that there was a significant influence from the use of foreign direct

Morschett, Schramm-Klein, Zentes, 2010

Koch, 2001

Berbel-Pineda \& Ramirez-Hurtado, 2011 investment as entry mode to the use of indicators as measure for export performance.

Source: Hollensen, Boyd, Dyhr Ulrich (2011)

The last hypothesis H10 explains the connection between the choice of entry mode (low to high control) and financial bottom line profit.

Financial Performance can be regarded in a transaction cost perspective as it indicates that companies select the entry mode that provides the lowest cost solution. In case of dealing with agents or distributors, firms are often exposed to opportunistic behaviour from their export partners and need to put costly safeguards in place, including complicated contracts and monitoring systems. In order to protect specific assets from information asymmetry and potential opportunistic behaviour, companies may choose higher control entry modes through some kind of ownership. In addition to safeguard issues, ownership provides better coordination and more efficient implementation of standardized strategies across borders. Thus, companies that are able to exploit ownership advantages through high control entry modes are expected to earn above average returns (Berbel-Pineda \& Ramirez-Hurtado, 2011; Qian, 1998). Consequently, companies' using high control modes are affecting the financial bottom line profit in a more positive direction than low control modes (Brouthers et al., 2003). This leads us to following hypothesis:

H10: The companies' use of high control modes is affecting the financial bottom line profit in a more positive direction, than low control modes.

\section{Methodology and Data Analysis}

The methodology is as the preceding study on the choice of foreign entry modes in a control perspective (Hollensen et al. 2011) based on a positivistic paradigm employing quantitative research techniques. The survey on Danish SMEs was conducted from 2002 until 2006 in collaboration between The Confederation of the Danish Industry (DI a private organisation consisting of 10,000 member companies) and The University of Southern Denmark. A random sample of 630 DI member companies was selected to answer a questionnaire consisting of 80 questions.

The data collection was conducted on-line and sent directly to the CEO, owner, export or marketing manager of the SME. The final research sample consisted of 170 companies (out of 630) who answered the questionnaire, providing a response rate of 27 percent. About 80 per cent of the respondents sell their products on the business to business market and reported more than 8 years export experience. Supporting previous research the responding SMEs primary motives for internationalization were risk diversification and growth opportunities (Jusjong, 2003). 
The objective of this study was to determine factors influencing the choice of foreign entry modes by Danish SMEs, seen in a financial and control perspective. A model showing the factors influencing the choice of entry mode was proposed along with 10 hypotheses (Figure 2). The entry modes are categorized into three groups depending on the level of control that the company has over its activities abroad.

The first category, high control modes, refers to using own sales subsidiary and selling directly to the foreign customer (often OEMs). In this case the Danish SME has high degree of control over its activities.

The second category, joint ventures and strategic alliances refers to the in-between high and low control modes, where the partners agree to share different resources, technology and profits over a longer time period.

The low control mode, the third category, refers to export through agents and distributors using an independent intermediate in the foreign markets or export through a Danish intermediate using a Danish based independent agent, distributor or commercial office (indirect export). In this setup the Danish SME has low degree of control over its activities.

In a first step of the data analysis of this complementing study correlations among entry mode and financial performance variables were measured. Table 2 shows the variables with significant correlation coefficients and where an influence on the bottom line results was assumed. Based on a standard $p$ value level $(p<0.05)$ the correlations show a positive association of the bottom line results with some high control modes. Positively or negatively correlated variables measure the degree to which a change of one variable is associated with the change of another (McDaniels \& Gates, 2008; Schmidt \& Hollensen, 2006). Table 2 therefore serves as indication to the research model which entry modes choices have an influence on the bottom line results.

Table 2. Correlations of entry modes and bottom line results

\begin{tabular}{llllllllll}
\hline & $\mathrm{a}$ & $\mathrm{b}$ & $\mathrm{c}$ & $\mathrm{d}$ & $\mathrm{e}$ & $\mathrm{f}$ & $\mathrm{g}$ & $\mathrm{h}$ & $\mathrm{bl}$ \\
\hline a: direct export & 1.000 & & & & & & & & \\
b: indirect export & 0.109 & 1.000 & & & & & & & \\
c: agents & -0.150 & -0.085 & 1.000 & & & & & & \\
d: joint venture/alliance & -0.015 & 0.088 & -0.038 & 1.000 & & & & & \\
e: subsidiary & -0.016 & -0.001 & -0.117 & 0.088 & 1.000 & & & & \\
f: acquisition & -0.015 & 0.005 & 0.046 & 0.081 & 0.183 & 1.000 & & & \\
g: distributor & -0.206 & 0.013 & 0.096 & 0.150 & 0.079 & 0.114 & 1.000 & & \\
h: other & -0.146 & -0.053 & -0.158 & -0.031 & -0.053 & -0.019 & -0.071 & 1.000 & \\
bl: bottom line & 0.041 & -0.114 & 0.242 & 0.169 & 0.219 & 0.147 & 0.087 & -0.231 & 1.000 \\
\hline
\end{tabular}

In a next step the variables were investigated in more detail according to hypothesis H10. The results of the correlation in Table 2 gave an answer to the question to which degree the bottom line results are positively influenced by the international activities. The respondents had to choose from a rating scale of 1 to $6(1=$ no relevance $6=$ high relevance) in terms of the importance of bottom line results. Table 3 shows a cross tabulation regarding the influence of entry mode choices on the bottom line result. The mean value was calculated to give an indication of which single entry modes were most relevant for the financial performance.

Table 3. Influence of entry mode decisions on bottom line results

\begin{tabular}{llllllllll}
\hline bottom line & $\mathrm{a}$ & $\mathrm{b}$ & $\mathrm{c}$ & $\mathrm{d}$ & $\mathrm{e}$ & $\mathrm{f}$ & $\mathrm{g}$ & $\mathrm{h}$ & $\mathrm{sum}$ \\
\hline 1 & 2 & 1 & 1 & 0 & 0 & 0 & 1 & 1 & 6 \\
2 & 2 & 0 & 2 & 0 & 1 & 0 & 0 & 0 & 5 \\
3 & 19 & 7 & 15 & 0 & 1 & 0 & 8 & 1 & 51 \\
4 & 33 & 13 & 31 & 4 & 7 & 1 & 12 & 0 & 101 \\
5 & 42 & 11 & 53 & 6 & 18 & 2 & 27 & 0 & 159 \\
6 & 11 & 0 & 13 & 3 & 5 & 2 & 3 & 0 & 37 \\
sum & 109 & 32 & 115 & 13 & 32 & 5 & 51 & 2 & 359 \\
mean value & 4,32 & 4,03 & 4,50 & 4,92 & 4,78 & 5,20 & 4,43 & 2,00 & \\
\hline
\end{tabular}


When looking at the entry mode categories $(\mathrm{A}=\mathrm{a}+\mathrm{e}+\mathrm{f}, \mathrm{B}=\mathrm{d}, \mathrm{C}=\mathrm{b}+\mathrm{c}+\mathrm{g})$ from a control perspective as used in the previous study Table 4 shows following results in mean values:

Table 4. H10 companies using high control modes achieve more positive financial results

\begin{tabular}{llll}
\hline $\begin{array}{l}\text { Mean values of influence } \\
\text { bottom line results }\end{array}$ & A: High control $(\mathrm{a}+\mathrm{e}+\mathrm{f})$ & B: Intermediate (d) & C: Low control $(\mathrm{b}+\mathrm{c}+\mathrm{g})$ \\
\hline International activities & 4.45 & 4.92 & 4.41 \\
\hline
\end{tabular}

In this categorization no support for H10 but a slight tendency towards intermediate control modes could be found. Therefore it can be stated that bottom line results have a positive influence on establishing joint ventures and alliances.

As Table 3 gives very different results in the high control mode A was divided into two categories. Direct selling to end-customers was split from the rest (FDI and WOS) because lower financial commitment in form of direct selling from home country to the end-customer could lead to less total control, and consequently lower profitability. The resulting mean values are shown in Table 5:

Table 5. H10 companies using high control modes achieve more positive financial results

\begin{tabular}{lllll}
\hline $\begin{array}{l}\text { Mean values of influence on } \\
\text { bottom line results }\end{array}$ & $\begin{array}{l}\text { A: High control A: High control } \\
\text { (FDI and WOS) }\end{array}$ & $\begin{array}{l}\text { B: Intermediate } \\
\text { (direct selling) }\end{array}$ & C: Low control \\
\hline International activities & 4.84 & 4.32 & 4.92 & 4.41 \\
\hline
\end{tabular}

When splitting up the high control mode into direct selling to end-customers and investment modes such as FDI and WOS, support can be found for higher investment modes. As a result it can be stated that high control modes (FDI and WOS) lead to more positive financial performance than all other entry modes. High control entry mode with low investment involved such as direct export thus leads to the lowest bottom line profits.

\section{Discussion of Survey Results}

This study addresses the debate about how the choice of foreign entry modes influences the financial performance of companies. Based on previous research in that area (e.g., Canabal \& White, 2008; Hultman et al., 2011; Kumar et al., 1994) the entry modes of Danish SMEs were investigated in a control perspective. The study contributes to current knowledge on entry mode decisions in two ways.

On the one hand, previous work on the choice of foreign entry modes in a control perspective (Hollensen et al. 2011) show limited support of the suggested dependencies. However, high correlations could be found for H5 where personal networks are used to establish long-term relationships in joint ventures or alliances. The tendency found for $\mathrm{H} 1$ gave an indication of how firm size or higher turnover will help a company to invest in foreign countries and use high control entry modes. As indicated in $\mathrm{H} 6$ a tendency towards low control entry modes could be found when activities on foreign markets have been stopped previously. The mentioned problem for $\mathrm{H} 8$ and $\mathrm{H} 9$ of grouping direct export and subsidiaries in one category was addressed in this complementary study. Whereas investing in a subsidiary should imply extensive planning and result in a better financial performance, this would not occur to the same extent for direct selling of products to foreign countries (For more details and data see Appendix B).

On the other hand, this survey shows that high control modes result in a higher bottom line profit through higher investments in the market and better implementation of cross border strategies. The transaction costs are reduced using higher investment modes such as FDI, WOS, JV or alliances. These findings support previous research where higher financial bottom line results were expected by exploiting ownership advantages through high control entry modes (Berbel-Pineda \& Ramirez-Hurtado, 2011; Qian, 1998; Brouthers et al., 2003).

Therefore the study indicates that entry mode decisions of Danish SMEs are on the one side influenced by personal networks that are of high value when seeking intermediate entry modes to foreign markets and by high turnover that enables the company to make stronger commitments in foreign countries. On the other side our findings shows how the entry mode choice influences the financial performance of international activities. These results can be utilized to identify managerial implications and directions for future research. 


\section{Conclusions and Managerial Implications}

Based on a survey of Danish SME's different factors that influence the choice of foreign entry modes were investigated in this paper. According to prior research SMEs' managers mostly use their intuition in selecting entry modes, whereas larger companies prefer a higher degree of control. Therefore we use the control perspective as the deciding factor for the categorization of the entry modes into high control, intermediate and low control mode.

Our first study results show that the most significant factor for the choice of high control entry modes was the factor turnover. The factors personal networks and the interruption of the international activities were the most important factors for the choice of intermediate mode. In the complementary study high correlations of entry mode decisions and in bottom line results were discovered. Here the grouping direct export and subsidiaries in one category was addressed and split into high investment and low investment modes. This new categorization leads to valuable insights because high control investment modes had the most positive influence on bottom line results. As a consequence it can be stated that the higher the investment the better the financial performance of an entry mode decision.

Three main implications can be drawn from the findings of the investigation from a managerial perspective. Firstly, companies should take many different factors into consideration when deciding how to enter a specific market since the choice of entry mode will affect the export performance. Secondly, companies should be more aware of the value of personal networks especially in regard to the selection of partners in joint ventures and strategic alliances. A broader approach to this partner selection will extend the access to network resources. Thirdly, companies investing more into markets reach a higher degree of control over their international activities and achieve better bottom line profit results. This provides international marketing managers with guidelines for choosing the most profitable entry mode for their company.

As this study mainly focussed on internal factors, future research could include external factors such as psychic distance and perceived risk to specific foreign markets. Environmental uncertainty is an important factor influencing foreign market entry. Institutional and cultural context variables determine such uncertainty and are included alongside traditional transaction cost variables to explain entry mode choices. The cultural distance between home and host country may influence managerial cost and uncertainty evaluations in target markets (Kogut \& Singh, 1988). The greater the cultural distance the higher the perceived environmental uncertainty and risk of foreign direct investments.

High control entry modes are more vulnerable to environmental uncertainties and risks because they are less flexible and involve higher irreversible investments (Hill et al., 1990). As environmental uncertainty increases, companies may choose low control and intermediate entry modes over high control modes in order to limit the risk exposure and increase operational flexibility (Luo, 2001; Kim \& Hwang, 1992). At the same time, risk and cost associated with cultural distance between host and target countries may be reduced by reduced ownership, in form of choosing lower control modes (Nielsen \& Nielsen, 2011; Slangen \& van Tulder, 2009).

Highlighting the need for more research attention in this area, our study results showed how higher investment in foreign countries effects the bottom line result in a positive way. Therefore future research could include more detailed and multidimensional indicators on export performance to achieve a better understanding of the complex and multi-faceted entry decision.

\section{References}

Agarwal, S., \& Ramaswami, S. N. (1992). Choice of foreign market entry mode: Impact of ownership, location and internalization factors. Journal of International Business Studies, 23(1), 1-27. http://dx.doi.org/10.1057/palgrave.jibs. 8490257

Andersen, O. (1997). Internationalization and market entry mode: a review of theories and conceptual frameworks. Management International Review, 37, 27-42.

Anderson, E., \& Gatignon, H. (1986). Modes of foreign entry: A transaction cost analysis and propositions. Journal of International Business Studies, 17(3), 1-26. http://dx.doi.org/10.1057/palgrave.jibs. 8490432

Arregle, J. L., Hébert, L., \& Beamish, P. W. (2006). Mode of international entry: The advantages of multilevel methods. Management International Review, 5, 597-618. http://dx.doi.org/10.1007/s11575-006-0117-3

Athanassiou, N., \& Nigh, D. (2002). The impact of the top management team's international business experience on the firm's internationalization: Social networks at work. Management International Review, 42(2), 
157-181.

Berbel-Pineda, J. M., \& Ramirez-Hurtado, J. M. (2011). Does the foreign market entry mode choice affect export performance? The case of the Spanish hotel industry. Journal of Business Economics and Management, 12(2), 301-316. http://dx.doi.org/10.3846/16111699.2011.573270

Brouthers, L. E., Nakos, G., Hadjimarcou, J., \& Brouthers, K. D. (2009). Key Factors for Successful Exxport Performance for Small Firms. Journal of International Marketing, 17(3), 21-38. http://dx.doi.org/10.1509/jimk.17.3.21

Brouthers, K. D., \& Hennart, Jean-Francios. (2007). Boundaries of the firm: Insights from international entry mode research. Journal of Management, 33(3), 395-425. http://dx.doi.org/10.1177/0149206307300817

Brouthers, K. D., Brouthers, L. E., \& Werner, S. (2003). Transaction cost-enhanced entry mode choices and firm performance. Strategic Management Journal, 24, 1239-1248. http://dx.doi.org/10.1002/smj.362

Canabal, A., \& White, G. O. (2008). Entry mode research: Past and future. International Business Review, 17 , 267-284. http://dx.doi.org/10.1016/j.ibusrev.2008.01.003

Carazo, P. C. M., \& Lumiste, R. (2010). Foreign entry modes of Colombian small and medium enterprises. International Journal of Business and Economics Perspectives, 5(1), 16-41.

Carneiro, J., Da Rocha, A., \& Da Silva, J. F. (2011). Determinants of Export Performance: a Study of Large Brazilian Manufacturing Firms. BAR Brazilian Administration Review, 8, 107-132. http://dx.doi.org/10.1590/S1807-76922011000200002

Carpenter, M. A., Sanders, W. G., \& Gregersen, H. B. (2001). Bundling human capital with organizational context: The impact of international assignment experience on multinational firm performance and CEO pay. Academy of Management Journal, 44, 493-511. http://dx.doi.org/10.2307/3069366

Chen, C., \& Messner, J. I. (2009). Entry mode Taxonomy for International Construction Markets. Journal of Management in Engineering, 25(1), 3-11. http://dx.doi.org/10.1061/(ASCE)0742-597X(2009)25:1(3)

Chen, Y. R., Yang, C., Hsu, S. M., \& Wang, Y. D. (2009). Entry mode choice in China's regional distribution markets: Institution vs. transaction costs perspectives. Industrial Marketing Management, 38, 702-713. $\mathrm{http}: / / \mathrm{dx}$.doi.org/10.1016/j.indmarman.2008.02.001

Cumberland, F. (2006). Theory Development within International Market Entry Mode - An Assessment. The Marketing Review, 6, 349-373.

Driscoll, A. M., \& Paliwoda, S. J. (1997). Dimensionalizing International Market Entry Mode Choice. Journal of Marketing Management, 13(1), 57-87. http://dx.doi.org/10.1080/0267257X.1997.9964459

Dunning, J. H. (1981). International production and the multinational enterprise. London: George Allen \& Unwin.

Ekeledo, I., \& Sivakumar, K. (2004). International market entry mode strategies of manufacturing firms and service firms: A resource-based perspective. International Marketing Review, 21(1), 68-101. http://dx.doi.org/10.1108/02651330410522943

Erramilli, M. K. (1991). The experience factor in foreign market entry behavior of service firms. Journal of International Business Studies, 22(3), 479-50. http://dx.doi.org/10.1057/palgrave.jibs.8490312

Erramilli, M. K., \& Rao, C. P. (1993). Service firms' international entry-mode choice: A modified transaction-cost analysis approach. Journal of Marketing, 57(3), 19-38. http://dx.doi.org/10.2307/1251852

Evans, J., Mavondo, F. T., \& Bridson, K. (2008). Psychic Distance: Antecedents, Retail Strategy Implications, and Performance Outcomes. Journal of International Marketing, 16(2), 32-63. http://dx.doi.org/10.1509/jimk.16.2.32

Gatignon, H., \& Anderson, E. (1988). The multinational corporation's degree of control over foreign subsidiaries: An empirical test of a transaction cost explanation. Journal of Law, Economics and Organization, 4(2), 305-336.

Gomes-Casseres, B. (1989). Ownership structure of foreign subsidiaries. Journal of Economic Behavior and Organization, 11(1), 1-25. http://dx.doi.org/10.1016/0167-2681(89)90061-9

Hayek, F. A. (1945). The Use of Knowledge in Society. American Economic Review, XXXV(4), 519-530.

Hennart, J. F. (1988). A transaction costs theory of equity joint ventures. Strategic Management Journal, 9 , 
361-374. http://dx.doi.org/10.1002/smj.4250090406

Herrmann, P., \& Datta, D. K. (2002). CEO successor characteristics and the choice of foreign market entry mode: An empirical study. Journal of International Business Studies, 33(3), 551-569. http://dx.doi.org/10.1057/palgrave.jibs.8491031

Herrmann, P., \& Datta, D. K. (2006). CEO experiences: Effects on the choice of FDI entry mode. Journal of Management Studies, 43(4), 755-778. http://dx.doi.org/10.1111/j.1467-6486.2006.00610.x

Hill, C. W. L. (1990). Cooperation, opportunism, and the invisible hand: Implications for transaction cost theory. Academy of Management Review, 15(3), 500-513.

Hill, C. W. L., Hwang, P., \& Kim, W. C. (1990). An eclectic theory of the choice of international entry mode. Strategic Management Journal, 11, 117-128. http://dx.doi.org/10.1002/smj.4250110204

Hollensen, S. (2010). Global Marketing - A decision-oriented approach (5th ed.). Harlow, UK: Pearson.

Hollensen, S., Boyd, B., \& Dyhr Ulrich, A. M. (2011). The choice of foreign entry mode in a control perspective. The IUP Journal of Business Strategy, 8(4), 7-31.

Horst, T. (1972). Firm and industry determinants of the decision to invest abroad: An empirical study. The Review of Economics and Statistics, 54(3), 258-266. http://dx.doi.org/10.2307/1937986

Hultman, M., Katsikeas, C. S., \& Robson, M. J. (2011). Export Promotion Strategy and Performance: The Role of International Experience. Journal of International Marketing, 19(4), 17-39.

Hymer, S. H. (1976). The international operations of national firms: A study of direct foreign investment. Cambridge, MA: The MIT Press.

Jusjong, L. (2003). Dansk Industri Internationalisering. InterResearch A/S: København.

Kim, W. C., \& Hwang, P. (1992). Global strategy and multinationals' entry mode choice. Journal of International Business Studies, 23(1), 29-53. http://dx.doi.org/10.1057/palgrave.jibs.8490258

Kindleberger, C. P. (1969). American business abroad: Six lectures on direct investment. New Haven, CO: Yale University Press.

Koch, A. J. (2001). Factors influencing market and entry mode selection: developing the MEMS model. Marketing Intelligence and Planning, 19(5), 351-361. http://dx.doi.org/10.1108/EUM0000000005652

Kogut, B., \& Singh, H. (1988). The effect on national culture on the choice of entry mode. Journal of International Business Studies, 19, 411-432. http://dx.doi.org/10.1057/palgrave.jibs.8490394

Kouznetsov, A., \& Jones, A. (2009). Conditions in Russia and their effects on entry mode decisions of multinational manufacturing enterprises: A qualitative study identifying issues for further research in the area of country conditions and their impact on entry mode. Marketing Management Journal, 19(1), 84-95.

Kumar, V., \& Subramaniam, Velavan (1997). A Contingency Framework for the Mode of Entry Decision. Journal of World Business, 32(1), 53-72. http://dx.doi.org/10.1016/S1090-9516(97)90025-0

Kumar, V., Stam, A., \& Joachimsthaler, E., A. (1994). An international multicriteria approach to identifying potential foreign markets. Journal of International Marketing, 2(1), 29-52.

Lages, L. F., Silva, G., Styles, C., \& Pereira, Z. L. (2009). The NEP Scale: A measure of network export performance. International Business Review, 18, 344-356. http://dx.doi.org/10.1016/j.ibusrev.2009.04.002

Lin, H. (2000). Choice of Market Entry Mode in Emerging Markets: Influences on Entry Strategy in China. Journal of Global Marketing, 14(1), 83-109. http://dx.doi.org/10.1300/J042v14n01_05

Yadong L. (2001). Determinants of entry in an emerging economy: A multilevel approach. Journal of Management Studies, 38(3), 443-472. http://dx.doi.org/10.1111/1467-6486.00244

Madsen, T. K. (1998). Executive insights: managerial judgment of export performance. Journal of International Marketing, 6(3), 82-93.

Makino, S., \& Neupert, K. E. (2000). National culture, transaction costs, and the choice between joint venture and wholly-owned subsidiary. Journal of International Business Studies, 31(4), 705-713. http://dx.doi.org/10.1057/palgrave.jibs.8490930

McDaniels, C., \& Gates, R. (2008). Marketing Research Essentials. Hoboken, NJ: Wiley.

Morschett, D., Schramm-Klein, H., \& Zentes, J. (2010). Strategic International Management. Wiesbaden: Gabler. 
http://dx.doi.org/10.1007/978-3-8349-6331-4

Morschett, D., Schramm-Klein, H., \& Swoboda, B. (2010). Decades of research on market entry modes: What do we really know about external antecedents of entry mode choice?. Journal of International Management, 16(1), 60-77. http://dx.doi.org/10.1007/978-3-8349-6331-4_13

Musso, F., \& Francioni, B. (2012). Foreign Markets Entry Mode Decision for Italian Small and Medium-Sized Enterprises. International Journal of Business and Management, 7(2), 3-16, http://dx.doi.org/10.5539/ijbm.v7n2p3

Nguyen, H. L. (2009). Parent Control Dynamics and International Joint Venture Performance. International Journal of Business and Management, 4(4), 29-41.

Nielsen, B. B., \& Nielsen, S. (2011). The role of top management team international orientation in international strategic decision-making: The choice of foreign entry mode. Journal of World Business, 46(2), 185-193. http://dx.doi.org/10.1016/j.jwb.2010.05.003

Nonaka, I., \& Takeuchi, H. (1995). The Knowledge-Creating Company. Oxford: University Press.

Oliveira, J. S., Cadogan, J. W., \& Souchon, A. (2012). Level of analysis in export performance research. International Marketing Review, 29(1), 114-127. http://dx.doi.org/10.1108/02651331211201561

Papadopoulos, N. (1988). Inventory, taxonomy and assessment of methods for international market selection. International Marketing Review, 5(3), 38-51. http://dx.doi.org/10.1108/eb008357

Papadopoulos, N., \& Martín, O. M. (2010). Toward a model of the relationship between internationalization and $\begin{array}{lllll}\text { export performance. International Business } & \text { Review, }\end{array}$ http://dx.doi.org/10.1016/j.ibusrev.2010.02.003

Pehrsson, A. (2008). Strategy antecedents of modes of entry into foreign markets. Journal of Business Research, 61(2), 132-140. http://dx.doi.org/10.1016/j.jbusres.2006.09.032

Peng, M. W., \& York, A. S. (2001). Behind Intermediary Performance in Export Trade: Transactions, Agents, and Resources. Journal of International Business Studies, 32(2), 27-346. http://dx.doi.org/10.1057/palgrave.jibs.8490955

Peng, M. W., \& Heath, P. S. (1996). The growth of the firm in planned economies in transition: Institutions, organizations, and strategic choice. The Academy of Management Review, 21(2), 492-528.

Polanyi, M. (1966/1997). The tacit dimension. In L. Prusak (ed.), Knowledge in Organizations (pp. 135-146).

Qian, G. (1998). Determinants of profit performance for the largest U.S. Firms 1981-92. Multinational Business Review, 6(2), 44-52.

Quer, D., Claver, E., \& Rienda, L. (2007). The impact of country risk and cultural distance on entry mode choice. Cross Cultural Management: An International Journal, 14(1), 74-87. http://dx.doi.org/10.1108/13527600710718859

Ramón, A. R. (2002). Determining factors in entry choice for international expansion. The case of the Spanish hotel industry. Tourism Management, 23(6), 597-607. http://dx.doi.org/10.1016/S0261-5177(02)00024-9

Rasheed, H. S. (2005). Foreign Entry Mode and Performance: The Moderating Effects of Environment. Journal of Small Business Management, 43(1), 41-54. http://dx.doi.org/10.1111/j.1540-627X.2004.00124.x

Sambharya, R. B. (1996). Foreign experience of top management teams and international diversification strategies of U.S. multinational corporations. Strategic Management Journal, 17, 739-746. http://dx.doi.org/10.1002/(SICI)1097-0266(199611)17:9<739::AID-SMJ846>3.0.CO;2-K

Sanchez-Peinado, E., Pla-Barber, J., \& Hébert, L. (2007). Strategic variables that influence entry mode choice in service firms. Journal of International Marketing, 15(1), 67-91. http://dx.doi.org/10.1509/jimk.15.1.067

Schmidt, M., \& Hollensen, S. (2006). Marketing Research: An International Approach. Harlow, UK: Pearson.

Singh, D. A. (2009). Export performance of emerging market firms. International Business Review, 18, 321-330. http://dx.doi.org/10.1016/j.ibusrev.2009.03.002

Slangen, A. H. L., \& Van Tulder, R. J. M. (2009). Cultural distance, political risk, or governance quality? Towards a more accurate conceptualization and measurement of external uncertainty in foreign entry mode research. International Business Review, 18(3), 276-291. http://dx.doi.org/10.1016/j.ibusrev.2009.02.014

Sousa, C., Martinez-Lopez, F., \& Coelho, F. (2008). The determinants of export performance: A review of the 
research in the literature between 1998 and 2005. International Journal of Management Reviews, 10(4), 343-374. http://dx.doi.org/10.1111/j.1468-2370.2008.00232.x

Styles, C., \& Ambler, T. (2003). The coexistence of transaction and relational marketing: Insights from the Chinese business context. Industrial Marketing Management, 32(8), 633-642. http://dx.doi.org/10.1016/j.indmarman.2003.06.004

Stoian, M. C., Rialp, A., \& Rialp, J. (2011). Export performance und the microscope: A glace through Spanish lenses. International Business Review, 20, 117-135. http://dx.doi.org/10.1016/j.ibusrev.2010.07.002

Tallman, S., \& Fladmoe-Lindquist, K. (2002). Internationalization, globalization and capacity-based strategy. California Management Review, 45(1), 116-135. http://dx.doi.org/10.2307/41166156

Thorelli, H. B. (1986). Networks: Between markets and hierarchies. Strategic Management Journal, 7(1), 37-51. http://dx.doi.org/10.1002/smj.4250070105

Tihanyi, L., Ellstrand, A. E., Daily, C. M., \& Dalton, D. R. (2000). Composition of the top management team and Firm International Diversification. Journal of Management, 26(6), 1157-1177. http://dx.doi.org/10.1177/014920630002600605

Trevino, L. J., \& Grosse, R. (2002). An analysis of firm-specific resources and foreign direct investment in the US. International Business Review, 11(4), 431-452. http://dx.doi.org/10.1016/S0969-5931(02)00018-5

Tung, R. L., \& Miller, E. L. (1990). Managing in the twenty-first century: The need for global orientation. Management International Review, 30(1), 5-18.

Williams, D. (1999). Foreign manufacturing firms in the UK: effects on employment, output, and supplier linkages. European Business Review, 99(6), 393-398. http://dx.doi.org/10.1108/09555349910300683

Williams, D. (2005). Supplier Linkages of Foreign-Owned Manufacturing firms in the UK. European Planning Studies, 13(1), 73-91. http://dx.doi.org/10.1080/0965431042000312415

Williamson, O. E. (1975). Markets and Hierarchies: Analysis and Antitrust Implications: A Study in the Economics of Internal Organization. New York: Free Press.

Williamson, O. E. (1985). The Economic Institutions of Capitalism. New York: Free Press.

Wheeler, C., Ibeh, K., \& Dimitratos, P. (2008). UK Export Performance Research: Review and Implications. International Small Business Journal, 26(2), 207-237. http://dx.doi.org/10.1177/0266242607086574

Zanfei, A. (2000). Transnational firms and the changing organisation of innovative activities. Cambridge Journal of Economics, 24, 515-542. http://dx.doi.org/10.1093/cje/24.5.515

Zhang, Y., Zhang, Z., \& Liu, Z. (2007). Choice of entry modes in sequential FDI in an emerging economy. Management Decision, 45(4), 749-772. http://dx.doi.org/10.1108/00251740710746015

Zou, S., Taylor, C. R., \& Osland, G. E. (1998). The EXPERF Scale: A Cross-National Generalized Export Performance Measure. Journal of International Marketing, 6(3), 37-58.

\section{Appendix}

Appendix A: Questions selected from the questionnaire for this study

What was the companies' turnover in million DKK last year?

- 0 - 10 mill. DKK

- $\quad 11-49$ mill. DKK

- 50 - 99 mill. DKK

- 100 mill. DKK and more

To how many countries do you export your product?

- $\quad 0$ - 3 countries

- $\quad 3$ - 9 countries

_ $\quad$ More than 10 countries

Please evaluate the below employee competences that you emphasize when internationalizing your business? (please rank each competence from $1=$ least important to $5=$ most important) 
_ $\quad$ Language skills

_ International experience

_ Cultural understanding

To which market is your company directed to?

_ B2C (Business-to-Consumer market)

_ $\quad$ B2B (Business-to-Business market)

- B2G (Business-to-Government market)

To which degree does the company use personal relations / networks for entering new markets? (please indicate the degree from 1 to 5: 1= Not important, 5= Very high degree)

Has the company previously stopped its activities in an international market?

- Yes

- No

To which degree does the company monitor its international suppliers?

(please indicate the degree from 1 to $5: 1=$ Not important, 5= Very high degree)

To which degree has the company planned its international expansion?

(please indicate the degree from 1 to $5: 1=$ Not important, 5= Very high degree)

Which indicators does the company use for measuring international market success?

(more answers are possible)

- Break even

- Market share

- $\quad$ Profit per market

- Sales volume

_ Competitive structure

Which entry modes does your company primarily use?

_ Subsidiaries / Direct selling to international customer (e.g. OEMs)

_ Joint ventures and strategic alliances

- Exports through agents, distributors or indirect exports through

- Danish intermediaries

To which degree is the bottom line profit affected by the company's international activities?

(please indicate the degree from 1 to $5: 1=$ Not important, 5= Very high degree)

Appendix B:

H1. Companies with a higher turnover are more likely to use high control modes

\begin{tabular}{lcccc}
\hline Turnover: & A: High control & B: Intermediate & C: Low control & sum \\
\hline 0 to 99 mio DKK & $40.65 \%$ & $4.21 \%$ & $55.14 \%$ & $100.00 \%$ \\
100 and more mio DKK & $43.21 \%$ & $4.94 \%$ & $51.85 \%$ & $100.00 \%$ \\
\hline
\end{tabular}

From the cross tabulation a slight tendency to support H1 can be seen from the higher percentage of A for turnover above 100 mio DKK as well as from the values for the low control mode. 
H2. Companies with a high degree of international experience are more likely to use high control modes

\begin{tabular}{llll}
\hline No of countries sold to: & A: High control & B: Intermediate & C: Low control \\
\hline 1 to 3 & $14.75 \%$ & $30.77 \%$ & $16.25 \%$ \\
4 to 9 & $40.16 \%$ & $46.15 \%$ & $35.00 \%$ \\
10 and more & $45.08 \%$ & $23.08 \%$ & $48.75 \%$ \\
sum & $100.00 \%$ & $100.00 \%$ & $100.00 \%$ \\
\hline
\end{tabular}

No support for $\mathrm{H} 2$ could be found when looking at the results from the above Table.

H3. Companies are more likely to use high control modes when they prefer employees with language skills, international experience and cultural understanding

\begin{tabular}{lccc}
\hline Mean values for employees with: & A: High control & B: Intermediate & C: Low control \\
\hline Language skills & 1.89 & 1.58 & 1.92 \\
International experience & 3.21 & 2.50 & 3.01 \\
Cultural understanding & 3.39 & 3.33 & 3.48 \\
\hline
\end{tabular}

In order to analyse which employee competences are important when looking at different entry modes the mean values were calculated in the above Table. A low mean value represents high relevance of these competences. The results do not support $\mathrm{H} 3$ but show a slightly higher importance of all competences for the intermediate entry mode.

H4. Companies selling products to the B2B market are more likely to use high control modes

\begin{tabular}{lccc}
\hline Market for products: & A: High control & B: Intermediate & C: Low control \\
\hline B2C & $22.44 \%$ & $29.41 \%$ & $21.90 \%$ \\
B2B & $63.46 \%$ & $64.71 \%$ & $63.81 \%$ \\
B2G & $14.10 \%$ & $5.88 \%$ & $14.29 \%$ \\
Sum & $100.00 \%$ & $100.00 \%$ & $100.00 \%$ \\
\hline
\end{tabular}

The above data shows that in all three entry modes the products are mostly sold to other businesses. The high values for the B2B market do not support $\mathrm{H} 4$.

H5. Companies with a high preference for personal networks are more likely to use intermediate modes

\begin{tabular}{lccc}
\hline Mean values for importance of: & A: High control & B: Intermediate & C: Low control \\
\hline Personal networks & 4.19 & 4.23 & 4.19 \\
\hline
\end{tabular}

Even though the absolute figures are much lower, the mean values shown above support for H5. The importance of personal networks is on average higher than for high or low control modes.

H6. Companies who have stopped their activities on an international market are more likely to use export (low control) modes

\begin{tabular}{lcccc}
\hline Stopped activities on an international market: & A: High control B: Intermediate & C: Low control & sum \\
\hline Yes & $44.17 \%$ & $2.50 \%$ & $53.33 \%$ & $100.00 \%$ \\
No & $39.43 \%$ & $5.71 \%$ & $54.86 \%$ & $100.00 \%$ \\
\hline
\end{tabular}

Slight support for H6 could be found when looking at the above Table. Companies that have stopped international activities on markets tend to use low control modes. 
H7. Companies with a high degree of monitoring suppliers are more likely to use high control modes

\begin{tabular}{lccc}
\hline Mean values for monitoring: & A: High control & B: Intermediate & C: Low control \\
\hline Suppliers & 4.08 & 4.38 & 4.09 \\
Value chain activities & 3.97 & 3.92 & 4.00 \\
External suppliers & 3.27 & 3.77 & 3.35 \\
\hline
\end{tabular}

The above data shows no support for $\mathrm{H} 7$ regarding monitoring of suppliers, value chain activities and external suppliers. Therefore an entry mode decision does not depend on the extent of monitoring which a company performs.

H8. Companies which have planned their international expansion are more likely to use high control modes

\begin{tabular}{lccc}
\hline Mean values for planning of: & A: High control & B: Intermediate & C: Low control \\
\hline International expansion & 4.03 & 4.00 & 4.11
\end{tabular}

A slight tendency towards low control modes can be identified from the above data. For this question the answers ranged from 1 to 6 , where a higher value indicates a higher relevance of planning the international expansion. Therefore $\mathrm{H} 8$ cannot be supported, but it was found that companies which have planned their international expansion rather use low control modes.

H9. Companies using indicators of international market success are more likely to use high control modes

\begin{tabular}{lcccc}
\hline Indicators: & A: High control & B: Intermediate & C: Low control & sum \\
\hline Break even & $42 \%$ & $5 \%$ & $53 \%$ & $100 \%$ \\
Market share & $41 \%$ & $4 \%$ & $55 \%$ & $100 \%$ \\
Profit per market & $43 \%$ & $4 \%$ & $53 \%$ & $100 \%$ \\
Sales volume & $44 \%$ & $4 \%$ & $52 \%$ & $100 \%$ \\
Competitive structure & $42 \%$ & $7 \%$ & $51 \%$ & $100 \%$ \\
sum & $33 \%$ & $0 \%$ & $67 \%$ & $100 \%$
\end{tabular}

For H9 no support but a slight tendency towards low control modes when using indicators of international market success could be found. 